\title{
Clover species cover on summer dry hill country in Central Otago
}

\author{
D.R. POWER ${ }^{1}$, K.M. POLLOCK ${ }^{2}$, R.J. LUCAS ${ }^{2}$ and D.J. MOOT ${ }^{2}$ \\ ${ }^{1}$ Cloudy Peak Station, 664 Ardgour Rd, Cromwell R.D. 3 \\ ${ }^{2}$ Agriculture and Life Sciences Division, P.O. Box 84, Lincoln University, Lincoln 7647
}

power.line@xtra.co.nz

\begin{abstract}
The prevalence of annual clover species and white clover (Trifolium repens) during the critical late winter to early summer period (mid Aug - Dec) are compared in relation to aspect, altitude, temperature and rainfall on Mt Grand at Hawea Flat. Measurements were at four north facing sites $(450,620,750,910 \mathrm{~m}$ a.s.1.) and one shady site at $630 \mathrm{~m}$ a.s.l. The rainfall was similar for all altitudes and aspects but annual clovers dominated on sunny faces and the perennial white clover dominated on the shady face with suckling ( $T$. dubium) the only adventive annual clover present. Annual cluster clover (T. glomeratum) dominated on the lower sunny faces at 450 and $620 \mathrm{~m}$ and sub clover (T. subterraneum) dominated at $750 \mathrm{~m}$. Suckling and striated clover $(T$. striatum) were present on all sunny aspect sites and were unaffected by altitude while haresfoot (T. arvense) presence increased with altitude. Air thermal time accumulation for the mid Aug-Dec period was $1440^{\circ} \mathrm{Cd}$ at the $450 \mathrm{~m}$ site and declined at $100{ }^{\circ} \mathrm{Cd}$ per $100 \mathrm{~m}$ of elevation $\left(\mathrm{r}^{2}=0.99\right)$. Thermal time at $910 \mathrm{~m}$ was $<1000$ ${ }^{\circ} \mathrm{Cd}$ and may limit seed production of some annual clover species at or above this altitude. The dominance of adventive annual clovers on the sunny aspects indicates areas that are probably suitable for introduction of improved annual species such as balansa clover (T. michelianum) or modern cultivars of sub. Productivity of perennial white clover which has persisted on the shady faces may be increased by more intensive grazing management.
\end{abstract}

Keywords: altitude, aspect, hill pastures, rainfall, spring production, thermal time, Trifolium arvense, $T$. glomeratum, T. dubium, T. repens, T. striatum, $T$. subterraneum.

\section{Introduction}

The intensification of hill and high country properties in the South Island frequently requires increased legume content to improve pasture quality. Oversown white clover has been the legume of choice but it frequently fails to persist on dry hill country (Knowles et al. 2003). Alternative legumes have been used with limited success due to difficulties in establishment (Awan \& Kemp 1994; Allan \& Chapman 1987).

Thermal time $\left({ }^{\circ} \mathrm{Cd}\right)$ requirements for germination and early growth and development of pasture grass and legume species have been used to quantify differences between species in rates of establishment and to explain the relative success of species when sown in mixtures (Moot et al. 2000; Black et al. 2002). Boswell et al. (2003) discussed the features of annual clover species and possible reasons for their distribution in New Zealand pastures and suggested that widespread species such as cluster clover could be used as biological indicators of sites for the introduction of more productive annuals such as subterranean or balansa clover. As a first step in this process the thermal time accumulation at different sites and seasons are assessed. These will be associated with the distribution of adventive legumes and used to discuss the possibility of introducing improved species at each site. The thermal requirements for flowering and seed production for many annual clover species have not yet been quantified but differences in the species prevalence in relation to the thermal time will provide an initial insight into the potential success of introductions of improved clovers.

The objectives of this research were to describe: (1) the distribution of clovers on sunny faces between 450 and $910 \mathrm{~m}$ a.s.1. compared with a shady aspect at $630 \mathrm{~m}$ a.s.l. in a 600-700 $\mathrm{mm}$ annual rainfall area of Central Otago, (2) the relationship between annual clover distribution and thermal time $\left({ }^{\circ} \mathrm{Cd}\right)$ and $(3)$ the adequacy of clover production and the potential for the introduction of new species.

\section{Methods}

\section{Site description}

The experiment was located at Mt Grand, the Lincoln University high country farm at Hawea in Central Otago. The property is typical of developed properties in Central Otago/Upper Clutha region rising from 360 to $1400 \mathrm{~m}$ above sea level with an average annual rainfall of 600 to $700 \mathrm{~mm}$. Soils associated with the sunny faces are Arrow steepland soils on moderately sloping hill country $\left(7^{\circ}\right.$ to $20^{\circ}$ ), with schist and loess parent material of medium to high nutrient status and are described as Semi Arid and Pallic soils (Blakemore 1968). These soil types comprise about 480 ha of Mt Grand Station's 2100 ha. Soil quick test values (Table 1 ) indicate adequate fertility at most sites but soil $\mathrm{pH}, \mathrm{P}$ and $\mathrm{S}$ are low on the south site (630S). The major pastoral limitations are summer moisture stress and low winter temperatures. 
Table 1 Soil Quick Test Results: Mt Grand, Central Otago and Ashley Dene, Canterbury

\begin{tabular}{lcccccccc}
\hline Site & slope & $\mathrm{pH}$ & $\mathrm{Ca}$ & $\mathrm{P}$ & $\mathrm{K}$ & $\mathrm{S}\left(\mathrm{SO}_{4}\right)$ & $\mathrm{Mg}$ & $\mathrm{Na}$ \\
\hline $450 \mathrm{~N}$ & $4^{\circ}$ & 5.8 & 6 & 14 & 6 & 3 & 16 & 1 \\
$620 \mathrm{~N}$ & $10^{\circ}$ & 5.5 & 3 & 14 & 6 & 4 & 12 & 1 \\
$750 \mathrm{~N}$ & $6^{\circ}$ & 5.5 & 4 & 17 & 7 & 8 & 14 & 1 \\
$910 \mathrm{~N}$ & $6^{\circ}$ & 5.4 & 4 & 32 & 7 & 11 & 13 & 1 \\
$630 \mathrm{~S}$ & $12^{\circ}$ & 5.2 & 3 & 6 & 5 & 3 & 12 & 1 \\
Ashley Dene $40 \mathrm{~m}$ a.s.I. & $0^{\circ}$ & 5.9 & 6 & 17 & 8 & 4 & 16 & 7 \\
\hline
\end{tabular}

Table 2 Mt Grand and Wanaka rainfall (mm) from five sites for 2001, 2002 and 2003 from 15 August to end of December covering the main growth period of annual clovers.

\begin{tabular}{ccccccc}
\hline & $450 \mathrm{~N}$ & $620 \mathrm{~N}$ & $750 \mathrm{~N}$ & $910 \mathrm{~N}$ & $630 \mathrm{~S}$ & $\begin{array}{c}\text { Wanaka Airport } \\
340 \mathrm{~m} \text { a.s.I. (NIWA) }\end{array}$ \\
\hline 2001 & 214 & 215 & 214 & 224 & 216 & 203 \\
2002 & 237 & 290 & 291 & 303 & 308 & 365 \\
2003 & 236 & 238 & 239 & 247 & 219 & 205 \\
mean & 229 & 247 & 248 & 258 & 247 & 224 \\
\hline
\end{tabular}

\section{Pastures}

The experimental areas at Mt Grand were located in lambing paddocks that were set stocked from mid September until weaning in late January or early February. In average years sunny faces dry off in late November and shady faces in late December.

White clover has been regularly oversown at $2 \mathrm{~kg}$ seed/ha every 2 or 3 years with maintenance fertilizer over Mt Grand hill country and is now fully established wherever the soil moisture regime is suitable. Sub clover seed has not been broadcast on this property for about 40 years. Mt. Barker is currently the dominant sub clover cultivar.

\section{Climate recording and cover scoring}

Four sunny face sites and one on the shady face were selected for temperature, rainfall and botanical cover data collection. The north facing sites were at 450, 620, 750 and $910 \mathrm{~m}$ a.s.1. $(450 \mathrm{~N}, 620 \mathrm{~N}, 750 \mathrm{~N}, 910 \mathrm{~N}$ respectively) and a south facing site at $630 \mathrm{~m}$ a.s.1. (630S) to provide an aspect comparison.

Temperature was recorded hourly at four levels at each site; soil (10 and $100 \mathrm{~mm}$ depths), grass minimum (frost) $(25 \mathrm{~mm})$ and air $(1.4 \mathrm{~m})$ by Hobo data loggers. Manual rain gauges were emptied monthly. Thermal time $\left({ }^{\circ} \mathrm{Cd}\right)$ accumulation was compared across the five sites for the $1.4 \mathrm{~m}$ air and soil temperatures using a base temperature of $0^{\circ} \mathrm{C}$. Data from lowland Canterbury (NIWA - Broadfields meteorological station) were also used for thermal time comparisons.

Spring observations ( $\%$ of ground cover) of individual species were made on a designated $16 \times 16 \mathrm{~m}$ area at each site. Observations dates were 9 September 2002, before ewes were set stocked for lambing, and then on 14 November 2002, 20 December 2002 and 21
December 2003. On each observation date, a $0.1 \mathrm{~m}^{2}$ quadrat was systematically moved about the site for a total of 10 locations and placed in a random manner. Cover data was then grouped into annual clover (striated, cluster, subterranean, suckling, haresfoot) and perennial clover (white). Other categories were annual grasses, perennial grasses, herbs and bare ground. Clover species data only are reported in this paper.

\section{Results \\ Rainfall}

Rainfall from the five Mt Grand weather stations averaged $520 \mathrm{~mm}$ per annum over the 2001-2003 period with the mean mid Aug-Dec rainfall being $246 \mathrm{~mm}$ (Table 2). Rainfall varied little with altitude or aspect, with similar mean rainfall at $620 \mathrm{~N}$ and $630 \mathrm{~S}$ in each year.

\section{Temperature}

Mean soil temperature at $100 \mathrm{~mm}$ at the lower sites rose to above $5^{\circ} \mathrm{C}$ around mid August. This provided a reference point for defining the start of the growing season for this experiment although the growing season would be expected to start later at higher altitudes. Mean $100 \mathrm{~mm}$ soil temperature from mid Aug-Dec was $12.5^{\circ} \mathrm{C}$ at $450 \mathrm{~N}$ and declined to $\sim 10.5^{\circ} \mathrm{C}$ at $910 \mathrm{~N}$. The soil temperatures at $10 \mathrm{~mm}$ depth showed greater diurnal variation than at $100 \mathrm{~mm}$ depth but the means over longer time periods were very similar. Air temperatures for this period declined steadily with altitude $\left(0.8^{\circ} \mathrm{C}\right.$ per $\left.100 \mathrm{~m} ; \mathrm{r}^{2}=0.99\right)$. Mean soil temperatures for all the north facing sites were generally higher than air temperatures from August onwards. In contrast, soil temperatures at $630 \mathrm{~S}$ did not rise above air temperatures until mid October (Fig. 1) yet the mean monthly air 
Figure 1 Mean monthly air and $100 \mathrm{~mm}$ soil temperature for the north-facing $620 \mathrm{~N}$ and south-facing $630 \mathrm{~S}$ sites at Mt Grand (mean 2001-2003).
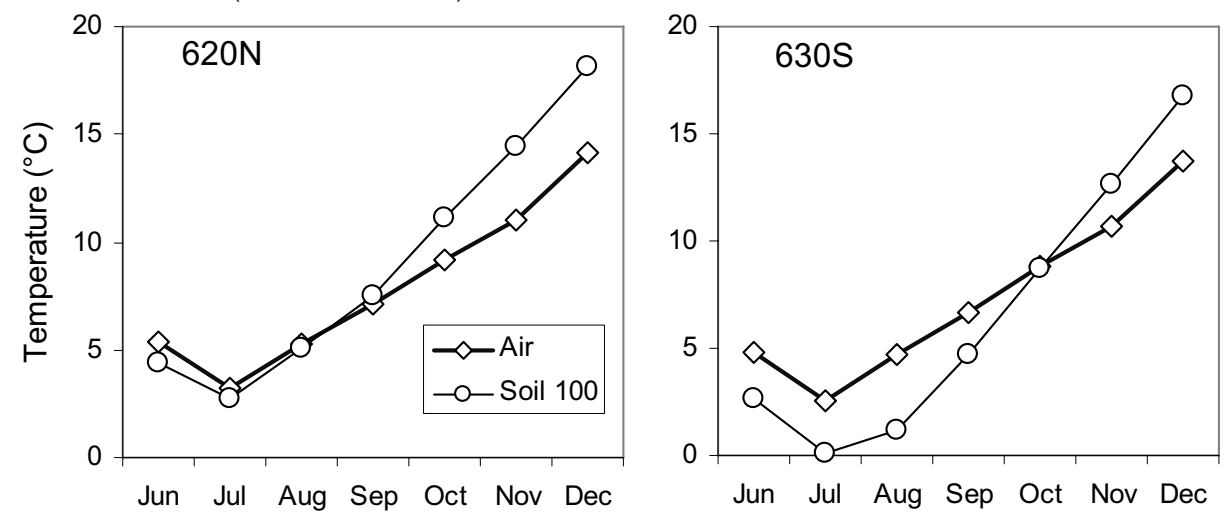

Figure 2 Mean air thermal time $\left({ }^{\circ} \mathrm{Cd}\right)$ for the five sites at Mt Grand and for lowland Canterbury near Ashley Dene (data from Broadfields Meteorological Station - NIWA) for the period 1 July-31 December for 2001, 2002 and 2003.

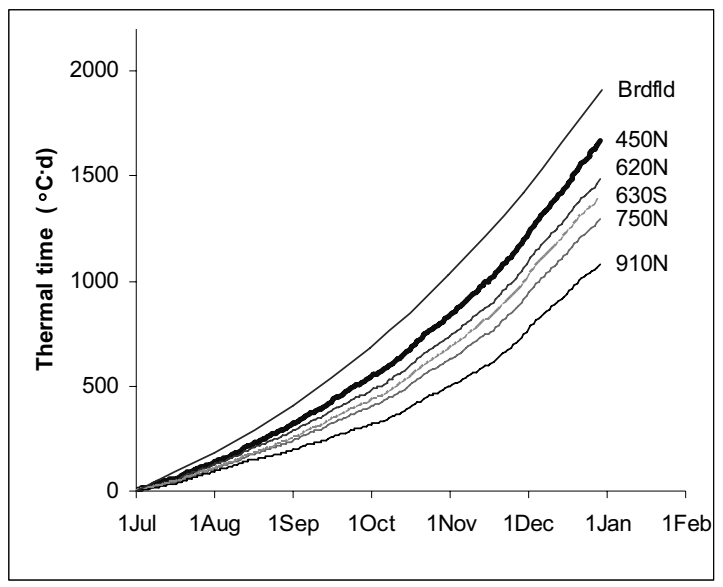

temperature at $630 \mathrm{~S}$ was only $0.4^{\circ} \mathrm{C}$ lower than at $620 \mathrm{~N}$.

Thermal times from 1 July to 31 December are compared across the five sites using the $1.4 \mathrm{~m}$ air temperature data (Fig. 2). Air thermal time for the spring growth period (mid Aug-Dec) was about $1440^{\circ} \mathrm{Cd}$ at $450 \mathrm{~N}$ and declined at $100^{\circ} \mathrm{Cd}$ per $100 \mathrm{~m}$ elevation $\left(r^{2}=\right.$ 0.99 ) to $<1000^{\circ} \mathrm{Cd}$ at $910 \mathrm{~N}$. The $630 \mathrm{~S}$ site with its southerly aspect had thermal time values between those for the $620 \mathrm{~N}$ and $750 \mathrm{~N}$ sites. Thermal time for $100 \mathrm{~mm}$ soil depth at each site was $100-400^{\circ} \mathrm{Cd}$ more than the 1.4 $\mathrm{m}$ air thermal time for the same 4.5 month period. The greatest increase occurred at the $620 \mathrm{~N}$ and $750 \mathrm{~N}$ sites which were strongly sloping to the NW. Comparative values taken from lowland Canterbury (NIWA) highlight the earlier start to significant spring accumulation of heat for plant growth and development.

Monthly grass minimum temperatures showed that $5-6^{\circ} \mathrm{C}$ frosts occurred at $450 \mathrm{~N}$ and $620 \mathrm{~N}$, increasing to $6-7^{\circ} \mathrm{C}$ frosts at $750 \mathrm{~N}$ and $910 \mathrm{~N}$ and $7-8^{\circ} \mathrm{C}$ frost at $630 \mathrm{~S}$.

\section{Botanical composition}

Pasture composition differed spatially with aspect and altitude on the sunny sites and temporally over the spring growth period. At 630S the dominant legume was white clover (20\% cover) and this reached a maximum of $40 \%$ cover in December 2002 (Fig. 3). Suckling clover at $10 \%$ cover, was the only adventive annual clover present. In contrast, mean white clover cover on sunny sites was $<5 \%$ except at $450 \mathrm{~N}$ in November 2002. Sub clover was found at all four sunny sites but the amount varied with altitude and over time. The initial observations in September 2002 confirmed the presence of sub at each altitude but by the end of spring $(20 / 12 / 02)$ live sub was not present at $450 \mathrm{~N}$ or $620 \mathrm{~N}$ but had $18 \%$ cover at $750 \mathrm{~N}$ and $5 \%$ at $910 \mathrm{~N}$. Cluster clover was the most prolific annual clover at $450 \mathrm{~N}$ and $620 \mathrm{~N}$ throughout both springs but only a trace of it was found at $750 \mathrm{~N}$ with none at $910 \mathrm{~N}$. Striated clover and suckling clover were present on all 
Figure 3 Percentage cover of clovers at five sites at Mt Grand during spring 2002 and December 2003. There were four northerly facing sites $(\mathrm{N})$ at $450,620,750$, and $910 \mathrm{~m}$ a.s.l. and one south facing site (S) at $630 \mathrm{~m}$.
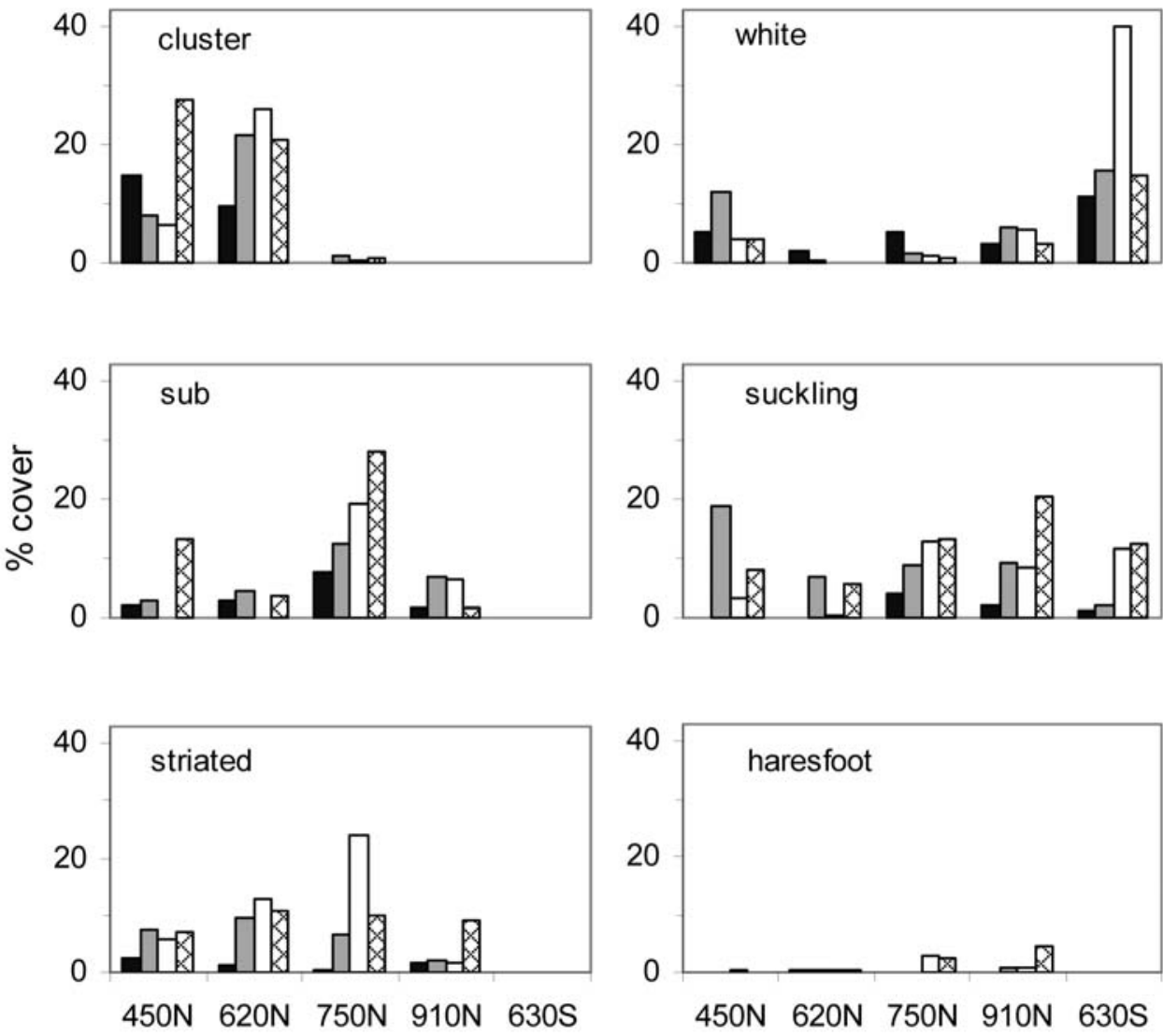
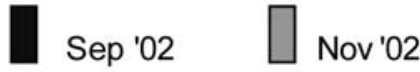

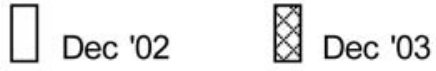

north facing sites and increased in cover as spring progressed. Only a trace of haresfoot clover was observed at $450 \mathrm{~N}$ and $620 \mathrm{~N}$ but it increased slightly at $750 \mathrm{~N}$ and $910 \mathrm{~N}$.

Bare ground was prominent on mid altitude north faces. Grasses on the north face were predominantly annual while $630 \mathrm{~S}$ was dominated by perennial grasses.

\section{Discussion}

The contrast in clover species composition between north and south aspects is dramatic given the similarity in rainfall across all sites and similarity of air thermal time at the $620 \mathrm{~N}$ and $630 \mathrm{~S}$ sites. The dominance of perennial species in the south facing pasture and annuals on the north faces may be attributed to the reduced evapotranspiration on the south faces. Although there is only a small reduction in the air thermal time during spring at $630 \mathrm{~S}$ compared with $620 \mathrm{~N}$ there is more energy for evapotranspiration on the north side because of the higher incident angle of solar radiation at the ground/pasture surface. The lower incident sun angle contributed to the 6-8 week delay in getting the soil temperatures above the mean air temperatures at $630 \mathrm{~S}$ compared to $620 \mathrm{~N}$.

Despite frequent oversowing over the whole property, white clover was the dominant clover only on the shady face with cover of $12-40 \%$ (cf. $<5 \%$ cover on sunny face sites) (Fig. 3). Knowles et al. (2003) emphasised the vulnerability of white clover in dryland pastures where its survival and regeneration was closely related to wetter than average summers. The only prominent annual clover at $630 \mathrm{~S}$ was suckling which reflected its adaptation to a wider range of environments than other annual clovers (Saxby 1956).

The annual clovers collectively dominated the four sunny face sites demonstrating their greater adaptation 
to long dry summers and the benefits of reduced competition from the shorter less dense grass sward. The most notable influence of altitude on the sunny face sites was the dominance of cluster clover over other clover species at $450 \mathrm{~N}$ and $620 \mathrm{~N}$ (Fig. 3). The presence of all annual clovers other than cluster at the two higher sunny sites indicates that total mid Aug-Dec thermal time was apparently sufficient for production of mature seed up to $910 \mathrm{~N}$.

Total mid Aug-Dec thermal time at $450 \mathrm{~N}$ of $1440^{\circ} \mathrm{Cd}$ was sufficient to achieve mature seed of all five annual clover species referred to in this paper. The $910 \mathrm{~N}$ site had $470^{\circ} \mathrm{Cd}$ less than $450 \mathrm{~N}$ and about $900^{\circ} \mathrm{Cd}$ less than Ashley Dene (Broadfield) where both sub and cluster clover thrive. However, the apparent advantage of the lowland Ashley Dene site would be tempered by earlier onset of summer drought in early November (Ates et al. 2006). Insufficient thermal time is likely to limit seed production of several clover species above $900 \mathrm{~m}$. Annual clover cover and seed production would also suffer when a dry autumn causes late germination followed by an early onset of summer drought.

Frost tolerance may provide an explanation for the larger amount of haresfoot and no reduction in suckling at $910 \mathrm{~N}$. Caradus (1995) used controlled environment rooms to show that haresfoot and suckling clovers were the most frost tolerant species; cluster and sub clover were in the most frost susceptible group; and striated and white clover were intermediate. The lack of sub clover on the south face may reflect the more severe frosts than on north faces. The distribution of clovers (Fig. 3) at the Mt Grand sites relates to some extent to those seedling frost tolerances.

Boswell et al. (2003) suggested that the presence of adventive clovers such as cluster could serve as bioindicators of areas where sub clover could be successfully introduced. Our observations on Mt Grand support their contention in so far as cluster clover may be less tolerant of frost than sub and the other adventive clovers but the resident cluster may have superior ability to complete its life cycle under greater water stress than the mid to late flowering Mt Barker sub clover. An earlier flowering cultivar of sub clover may therefore be better adapted to the driest parts of the lower north faces such as the $620 \mathrm{~N}$ site where cluster was most prominent and sub cover was less than at $450 \mathrm{~N}$ and $750 \mathrm{~N}$.

These data can help identify site-adapted species such as balansa clover and their improved cultivars with late or early flowering.

\section{ACKNOWLEDGEMENTS}

Valuable cooperation from Gordon Meikle, (Mt Grand manager) and enthusiastic assistance with the field work from Elliot Scott was much appreciated.

\section{REFERENCES}

Allan, B.E.; Chapman, H.M. 1987. Oversown tussock country: lessons from 30 years of improvement and management of Tara Hills. Proceedings of the New Zealand Grassland Association 48: 77-81.

Awan, M.H.; Kemp, P.D. 1994. Comparison of oversowing methods for pasture legume establishment on slopes. pp 31-35. In: Proceedings of the Agronomy Society of New Zealand 24.

Ates, S; Brown H.; Lucas, R.; Edwards, G. 2006. Effect of ewe stocking rate in spring on subterranean clover persistence and lamb liveweight gain. Proceedings of the New Zealand Grassland Association 68: XXX.

Black, A.D.; Moot, D.J.; Lucas, R.J. 2002. Seedling development and growth of white clover, Caucasian clover and perennial ryegrass grown in field and controlled environments. Proceedings of the New Zealand Grassland Association 64: 197-204.

Boswell, C.C.; Lucas, R.J.; Fletcher, A.; Moot, D.J. 2003. The ecology of four annual clovers adventive in New Zealand grasslands. Legumes for dryland pastures. Ed. Moot, D.J. Grassland Research and Practice Series 11: 175-184.

Blakemore, L.C. 1968. General Survey of the soils of the South Island, New Zealand. In: New Zealand Soil Bureau Bulletin 27.

Caradus, J.R. 1995. Frost tolerance in Trifolium species. New Zealand Journal of Agricultural Research 32: 157-162.

Knowles, I.M.; Fraser, T.J.; Daly, M.J. 2003. White clover: loss in drought and subsequent recovery. Legumes for dryland pastures. Ed. Moot, D.J. Grassland Research and Practice Series 11: 37-42.

Moot, D.J.; Scott, W.R.; Roy, A.M.; Nicholls, A.C. 2000. Base temperature and thermal time requirements for germination and emergence of temperate pasture species. New Zealand Journal of Agricultural Research 43: 15-25.

Saxby, S.H. 1956. Annual Clovers. pp. 96-101. In: Pasture production in New Zealand. NZ Department of Agriculture Bulletin No 250. 